\title{
What Explains Ethnic Organizational Violence? Evidence from Eastern Europe and Russia ${ }^{1}$
}

\author{
Version accepted in Conflict Management and Peace Science
}

\author{
Victor Asal \\ University at Albany - State University of New York \\ Brian J. Phillips \\ Centro de Investigación y Docencia Económicas (CIDE) \\ Citation: Asal, Victor and Phillips, Brian J., 2018. What explains ethnic organizational \\ violence? Evidence from Eastern Europe and Russia. Conflict management and peace science 35 \\ (2), pp.111-131.
}

\begin{abstract}
Why do some ethnopolitical organizations use violence? Research on substate violence often uses the state level of analysis, or only analyzes groups that are already violent. Using a resource mobilization framework drawn from a broad literature, we test hypotheses with new data on hundreds of violent and nonviolent ethnopolitical organizations in Eastern Europe and Russia. Our study finds interorganizational competition, state repression and strong group leadership associated with organizational violence. Lack of popularity and holding territory are also associated with violence. We do not find social service provision positively related to violence, which contrasts with research on the Middle East.
\end{abstract}

Key words: ethnic violence, outbidding, organizational dynamics, Eastern Europe, Russia

Acknowledgement: This material is based upon work supported by the Science and Technology directorate of the US Department of Homeland Security under Grant Award Numbers N00140510629 and 2008-ST-061-ST0004, made to the National Consortium for the Study of Terrorism and Responses to Terrorism (START, www.start.umd.edu). The views and conclusions contained in this document are those of the authors and should not be interpreted as necessarily representing the official policies, either expressed or implied, of the US Department of Homeland Security or START.

\footnotetext{
${ }^{1}$ Replication data and Online Appendix will be available at https://sites.google.com/site/brianjphillips/.
} 


\section{Introduction}

"The school's teacher, Sara Mogammedovna, a stern but cheerful 42-year-old, has educated an entire generation of Samashki children...Standing outside her closed school by order of the Russian command - she points at the bullet holes that scar the building. "At last count, I lost 100 of my children," she says, adding that during the first war, when the Russians entered Samashki during 'cleansing operations,' they would walk by groups of children and shoot at them. "We don't teach children history," she continues. "The children teach us. I sleep in the same bed with my ten-year-old. He says, 'When I am 13 or 14, just let me go and kill one Russian (di Giovanni 2000).'”

What explains ethnic violence? More specifically, why do some factions claiming to represent an ethnic group engage in violence, while many others do not? To what extent do organizational attributes matter, as opposed to state attributes? Janine di Giovanni's article "Evil Things Happened Here," which provides a snapshot of the Chechen war and the treatment of the Chechen people by the Russian military, makes a compelling argument for seeing government repression and discrimination being the driving force behind the turn to violence (di Giovanni 2000). The attacks had a significant impact on the nature of the Russian state and impacted and entrenched a repressive state effort toward dealing with violence in the Caucuses (Lynch 2005). Not surprisingly, much of the literature about Beslan is not focused on the politics of the attack but the traumatic impact on survivors (see for example Moscardino et al. 2007).

Two of the key explanations offered for the attack at Beslan are revenge and ethnonationalism (see for example Ó Tuathail 2009). As Chivers reports, the terrorists at Beslan told their hostages, "We are from Chechnya," and continued: "This is a seizure. We are here to start the withdrawal of troops and the liberation of Chechnya (Chivers 2007)." Literature on ethnic conflict affirms the importance of repression and discrimination for the use of violence by ethnic groups (Gurr 2000, Cederman, Wimmer, and Min 2010). 
What is missing, however, from much of the literature is an examination of why these groups, as opposed to other ethnopolitical organizations, use violence in the first place. The literature on political violence often focuses on state-level attributes (see for example Regan and Norton 2005). A number of scholars have begun to analyze organizational aspects of civil conflict (Cunningham 2006; Cunningham, Gleditsch, and Salehyan 2009; Pearlman and Cunningham 2012), but they focus on already-violent organizations, which limits our understanding of why certain organizations use violence while others do not. ${ }^{2}$ Ethnopolitical groups often engage in protests, lobbying, and other actions instead of violence. They seek to represent their community, sometimes provide social services, and engage in other non-violent activity. Indeed, of the hundreds of Eastern European ethnopolitical organizations analyzed in this article, fewer than $20 \%$ ever use violence.

The current study intends to take a step back in the process and focus on which groups select violence, as other research takes such choices for granted. ${ }^{3}$ Other studies use the entire ethnic group as the unit of analysis (Gurr 2000; Cederman, Wimmer, and Min 2010). This does not allow one to address the question of why particular organizations use violence and others do not. Chechens did not attack Beslan, but a specific organization - the Riyadus-Salikhin group did. By focusing on the organizational level and looking at both violent and nonviolent organizations, we are able to examine government repression and ethnonationalism in a more

\footnotetext{
${ }^{2}$ For an important exception to this general limitation in the quantitative literature on nonstate actor political violence see, for example, Chenoweth and Stephan (2011).

${ }^{3}$ This is consistent with research that, instead of studying terrorist groups, sought to understand why some political parties became or created terrorist groups (Weinberg 1991).
} 
precise and directed way. We can also see what other organizational factors are important in explaining why some groups use violence while others do not.

To do this we turn to a new dataset called the Eastern European Minorities at Risk Organizational Behavior (MAROB) dataset, which covers organizations that claim to represent ethnic or ethno-religious groups in Eastern Europe and Russia. The data provides yearly data on 271 diverse organizations for a 15-year time period, and it includes organizations that are both violent and nonviolent. All the groups in the dataset are identified as organizations that claim to represent Minorities at Risk (MAR) groups as identified by Gurr (2000). The organizations must be politically active for at least three years and operate beyond the local level. The dataset excludes groups created by governments. It is important to note when making generalizations that the dataset is limited because it focuses specifically on the Eastern European area. However, it gives us the important advantage of being able to consider both violent and nonviolent organizations over time, and to examine a wide variety of possible factors that the literature has suggested might affect the use of violence.

In the sections below we emphasize the importance of studying organizations, particularly the wider sample of both violence and nonviolent groups. Shortcomings in the civil conflict literature in particular are discussed. Using a focus on organizational resources, we present a number of related hypotheses for why a group might use violence. We then describe the data with more detail as well our methodology, and our then present our findings. The results suggest that group violence is associated with interorganizational competition, state repression and the group's resources. Internal organizational factors such as leadership type are also associated with violence. Unpopular groups are more likely to use violence as well. Interestingly, whether the group provides social services is not associated with the use of violence. 


\section{What explains ethnic violence?}

For decades, scholars have attempted to explain how political violence relates to ethnic identity and organization (e.g., Horowitz 1985). Two highly-cited articles suggest that there is no connection between ethnic grievances and civil conflict (Fearon and Laitin 2003, Collier and Hoeffler 2004). Neither study found a consistent relationship between a country's ethnic diversity and propensity toward civil war onset, but they found onset related to economic factors. They interpreted this to mean that ethnic grievances are an insufficient condition for starting civil conflict, and material factors such as potential recruits, funding, and a weak government are necessary conditions for the opposition to engage in serious violence against the state.

The supposed lack of connection between ethnic factors and the start of civil conflict was surprising because the majority of civil wars have an ethnic component. For example, Sambanis (2001, 269) finds that of the 109 civil wars that started between 1960 and 1999, 77 were ethnic wars, while only 32 were revolutionary wars. Scholars have made a great deal of progress seeking to explain causal pathways between ethnic group dynamics and domestic violence. A number of studies have used the entire ethnic group (e.g., Hutus, Basques, etc.) as unit of analysis, most notably the work of Gurr and colleagues (Gurr and Moore 1997, Gurr 2000). Cederman, Wimmer, and Min (2010) also study ethnic groups, and show that the extent to which the group is represented in the government can explain political violence.

Using the country as the unit of analysis, many other studies have shown how ethnic issues contribute to violence, with some studies directly refuting the work of Fearon and Laitin and Collier and Hoeffler. For example, Hegre and Sambanis (2006) show that, upon further 
analysis, there is often a relationship between ethnic fractionalization and civil war onset.

Montalvo and Reynol-Querol (2005) find that ethnic polarization is robustly associated with the onset of civil war. Bhavnani and Miodownik (2009) find that the effect of polarization on civil war propensity is conditional on levels of ethnic salience. Blimes (2006) also finds an indirect relationship involving ethnicity, suggesting that, for example, a state's total population size is only associated with its likelihood of civil war onset at higher levels of ethnic fractionalization. Government type can play a role in ethnic violence, as there are debates about how ethnofederalism or similar systems affect the likelihood of ethnic conflict (Bunce 2004, Roeder 2009, Christin and Hug 2012).

The research thus far on ethnic dynamics and subnational violence, as noted in the introduction, is incomplete in a number of ways. First, the studies that use the state as the unit of analysis black-box many aspects of causal mechanisms. This broad unit of analysis can be problematic because it can overlook specific interactions with the state, such as whether repression actually targeted a group that later used violence. Second, the studies that analyze entire ethnic groups also leave questions unanswered. In many cases, some factions of an ethnic group engage in violence while others do not. Not every member of the ethnicity, and not every group claiming to represent the community, takes up arms. Finally, studies that focus only on civil war as an outcome truncate a great deal of political violence. By looking at lower levels of conflict, we contribute to understanding violence as a process, with many important causal factors along the way to what might eventually become a larger conflict. Given that the literature suffers from a deficiency of organizational explanations for political violence, and ethnic violence more specifically, the following section presents of number of relevant hypotheses. 


\section{Ethnopolitical organizations, resources, and violence}

A premise underlying the hypotheses presented here is that organizational dynamics are fundamental for understanding political violence, including ethnic violence. This approach can be contrasted with frameworks emphasizing state regime type (Saideman et al. 2002), or elites (Kaufman 2006), for example. Given the focus on the organizational level, we further assume that subnational organizations' quest for resources should be essential in explaining behavior of these groups (McCarthy and Zald 1977; Wilson 1973). The particular behavior we focus on in this article is violence, but of course the logic can be applied to other outcomes as well. As organizations seek to gather and retain resources - such as members and funds - they interact with other groups, and the state, and these interactions affect their ability to mobilize such resources. The resource pressures caused by these interactions should affect a group's decision to use violence. Additionally, groups have a variety of potential sources for resources, and some should be especially likely to lead to the organizational decision to engage in violence. Finally, other group resources, or the way resources are deployed, such as controlling territory or providing social services, enable the group to use violence more effectively than other groups.

\section{Interorganizational competition}

In many contexts, multiple organizations claim to represent the same ethnic group. This often leads at least some of the organizations to take up violence. When multiple groups claim to represent the same ethnic population, these groups compete for finite resources, such as members and donations. This emphasis on groups' efforts to gather necessary assets is consistent with studies of organizations and organizational survival (e.g., Wilson 1973). Organizational competition can lead to violence through at least two mechanisms: First, a group, seeing another as a threat to its resource base, and therefore survival, might attempt to physically coerce the 
other into disbanding or reducing its footprint. This suggests violence between the competing groups. Second, competition might encourage a group to employ violence as an innovation that can draw increased attention from the ethnic population. This suggests violence directed against the state or some other ethnic population, for example. Della Porta (2013) argues that "competitive escalation" often pushes political groups to violence, and she cites a number of examples from around the world.

Other arguments in the literature suggest similar outcomes, regardless of whether a group is specifically ethnically motivated. Bloom's $(2004,2005)$ “outbidding” argument suggests that interorganizational competition leads groups to adopt extreme tactics, such as suicide attacks, and shows evidence of this in diverse locations such as Israel and Sri Lanka. Beyond suicide attacks, a recent study finds that increased competition between terrorist groups leads to more shocking types of violence (Conrad and Greene 2015). Competition can also contribute to organizational endurance, as militant groups learn from each other and gain new incentives from their violent rivalry (Phillips 2015). Democratic competition, in terms of more interest groups, has also been shown to be associated with an increased possibility of violence (Chenoweth 2010). Furthermore, research suggests that when an opposition movement is attempting to bargain with the government, if the movement is divided, it is more likely that a civil war breaks out (Cunningham 2013). The current study analyzes much lower levels of violence, but the logic is consistent. Overall, as organizations compete with each other, they should have a greater chance of using violence.

H1: Organizations competing with other organizations are more likely to use violence than organizations not in competition. 
While there is a solid theoretical basis for the above hypothesis, testing it is important because of mixed evidence in the literature regarding outbidding. Some studies find that group competition is not associated with violence (Findley and Young 2012), and other research only finds a relationship that is conditional on other factors (Nemeth 2014). Overall, additional empirical testing of the outbidding hypothesis is needed to determine if it finds support, and under what conditions - such as in particular regions.

\section{Repression}

A broad literature explores the consequences of state repression, with complex relationships shown to exist between state crackdowns and subnational mobilization or protest (e.g., Lichbach 1987, Opp and Roehl 1990, Inclan 2009). Regarding violence as an outcome, the literature is clearer: subnational violence is likely after the state represses (Lichbach 1987, Regan and Norton 2005, Francisco 2005). Why can state repression be counterproductive? In other words, why does it lead to an outcome that the state would prefer to avoid, violence by a subnational organization? An underlying assumption is that subnational political groups have a set of tactics available to them, their repertoire (Tilly 1978), and repression reduces the scope of activities available to these groups. This limitation in their choice of tactics shapes groups' actions. Crackdowns on protest, paradoxically for repressive regimes, can give rise to substitute forms of expression such as violence (Francisco 2005). Groups unable to participate in legal politics do not have the same resources available to them as legal groups do, such as possibly access to government funds, or certain rights to media coverage. As a result, they are more likely turn to violence (Powell Jr 1982). This is consistent with research on terrorism, which suggests that hurdles to subnational groups' legal political participation increase the likelihood of that type of violence (Aksoy, Carter, and Wright 2012; Braithwaite, Foster, and Sobek 2012). 
Repression does not encourage subnational violence simply because it reduces the nonviolent options available to political groups. Karklins and Peterson (1993) found that harsh state reactions to subnational political groups in Eastern Europe during 1989 served as "focal events" for group members and sympathizers, emboldening them. Studying the same period in East Germany, Lohman (1994) argues that state over-reaction ignited an informational cascade, exposing a darker side of the state. This, too, could embolden groups to engage in violence. (Informational cascades are generally theorized to explain mobilization, not necessarily violence, but violence is a possible related outcome.) Through these mechanisms, repression helps political groups mobilize resources and radicalize (Francisco 2005). Overall, when a state engages in repression toward a group, this should increase the likelihood that the group engages in violence.

$\mathrm{H} 2$ : Organizations experiencing state repression are more likely to use violence than organizations not experiencing repression.

Organization and mobilization dynamics: Leadership and popularity

Organizations differ greatly regarding internal dynamics. The structure of groups can vary from a hierarchical group with a powerful leader to a "horizontal" network-type group (Arquila and Ronfeldt 2001; Kilberg 2012). In the middle are groups such as those with a decentralized leadership, or groups led by councils. These differences have implications for political group behavior. On the one hand, network-structured groups are better at evading government repressive tactics and can be more resilient against leadership arrests. On the other hand, groups with stronger leaders can be more efficient. In general regarding organizational structure, dissident groups face a tradeoff between security and efficiency (Kilberg 2012). For 
example, hierarchical subnational militant groups are more lethal than network-structure groups (Heger, Jung, and Wong 2012).

Beyond efficiency, centralized groups might be more likely to engage in violence because the organizational decision to use violence - which can be costly and backfire - can occur more quickly, without debate, in such a group. A strong leader, often charismatic in political organizations, should be better able to motivate a group to engage in violence. Once the decision is made to use violence, such a group type should be better equipped to carry out violence. ${ }^{4}$ In general, however, we believe that groups with strong leaders should be more likely to use violence.

H3: Organizations with strong leaders are more likely to use violence than organizations without strong leaders.

Ethnopolitical organizations are not only affected by their internal dynamics, but also their relationship with the wider ethnic community they claim to represent. Most ethnopolitical organizations do not use violence, so those that do are unusual - perhaps in their relationship with the state, perhaps in their relations with the broader community. If a group is considered on the "fringe," without much popular support, it might turn to extreme means to draw more support, or just to achieve its goals without such support. One obvious type of extreme tactic that

\footnotetext{
${ }^{4}$ Empirical evidence on this is somewhat mixed. For example, a study of Middle Eastern militant groups finds that groups with leadership deficits are more likely to use terrorism (Abrahms and Potter 2015). This is not directly comparable to the present study, which analyzes both violent and nonviolent groups, and looks at the outcome of general violence instead of terrorism. However, it is noteworthy that group leadership has various effects on the use of violence.
} 
a fringe group could use is violence. In other words, the groups feel that they have "no other way out," to use Lenin's phrase, quoted notably by Goodwin (2001).

H4: Organizations that are less popular with the wider community are more likely to use violence than more popular organizations.

\section{Financial resources: Foreign state and diaspora support}

Violence can be costly. A subnational political organization should be more likely to engage in violence if it has means to pay the literal costs associated with physical conflict. The use of violence presents financial issues for subnational political groups in two ways: First, violence can bring more direct costs, in terms of purchasing weapons and other tools to actually carry out the violence. Violence is costly to groups because of immediate expenses it entails, such as purchasing firearms or explosives. If a group is more grassroots and self-funded, it might prefer to stick to lower-cost non-violent political action, such as protest or petitions. However, if a group has a substantial source of income, it is likely to at least consider the possibility of adding higher-cost tactics to its repertoire, including violence. Note that this is not a study of large-scale violence such as civil war, where funding has been shown to be crucial. However, even lower levels of violence are costly (e.g., Giraldo and Trinkunas 2007), so there is still likely to be some role for funding ability in group violence.

Second, violence requires especially dedicated members, and a common way to keep members motivated is through financial incentives. Mobilizing support for any political activity has its costs (e.g., Lichbach 1995), but involvement in political violence brings high costs, including the potential for state sanctions and physical harm. To get members to participate in violence, or to stay in an organization involved in violence, a group should be especially able to offer incentives, selective benefits, to its members. There are a number of different types of 
incentives a group can provide (Wilson 1973), but financial incentives are especially important. This is not to suggest that all members of ethnopolitical groups are simply working for paychecks, but that the group's ability to provide financial incentives to members increases the likelihood of members' continued participation. ${ }^{5}$ This is consistent with opportunity cost arguments for rebel recruitment in civil conflict (Collier and Hoeffler 2004).

We consider two types of revenue sources for subnational political groups - state support and diaspora support. These types of income flows, more than other sources, should be likely to be associated with violence because they come from outside the country in which the group primarily operates. This means there is less chance for the state or other domestic actors to sanction the funding source when the recipient group uses violence. Foreign state support has been shown to have important consequences for terrorist groups that receive it (Byman 2005; Carter 2012), as well as civil war participants (Balch-Lindsay and Enterline 2000, Regan 2002). Similarly, research has shown that diaspora connections and support can help co-ethnic groups involved in crime (Williams 2001, Paoli and Reuter 2008), as well as groups involved in civil conflict (Collier and Hoeffler 2004). However, the literature has not yet considered how either type of foreign assistance might affect other types of groups, such as subnational ethnopolitical groups. Based on the above arguments - that income sources make a group more likely to engage in violence, and foreign income should especially make violence probable - we propose the following hypotheses.

${ }^{5}$ Ethnopolitical groups probably do not depend on monetary incentives as much as, for example, criminal organizations do, but there is nonetheless substantial evidence of financial incentives playing an important role for such subnational political organizations (Wilson 1973, Weinstein 2006, Shapiro 2013). 
H5: Organizations receiving foreign state support are more likely to use violence than organizations without foreign state support.

H6: Organizations receiving diaspora support are more likely to use violence than organizations not receiving diaspora support.

Note that there is an alternative possibility: that ethnopolitical groups are more likely to resort to violence when they lack funds. This assumes that funding helps groups to achieve change through legitimate and nonviolent means, and groups only take up arms out of financial desperation. This is consistent with research showing that violence, or at least terrorism, is used by weak or dysfunctional organizations (e.g., Abrahms and Potter 2015). The empirical tests will evaluate whether these two funding sources are associated with more violence, less violence, or not at all.

\section{Resources and their use: Territorial control and social service provision}

Control of territory is often a step in the direction of independence, and represents a challenge to a state's legitimacy (Ford 2005, Mampilly 2007). Organizations that control territory are likely to be groups that are interested in breaking away from the state, and thus more likely to use violence against the state as a means to defend against state encroachment and as a tool to build towards independence. This clearly was the situation in the case of Chechnya (Lieven 1998). Control of territory is also a basis for resource extraction that would allow an organization to incentivize individuals to participate in violence (Collier et. al 2003, Collier and Hoeffler 2004, Makarenko 2004). When an organization controls territory its capability to carry out attacks should go up dramatically because territory can “....accommodate entire training complexes, arms depots, and communications facilities (Takeyh and Gvosdev 2002, 98).” 
Indeed, Sánchez-Cuenca and de la Calle (2009) posit control of territory as one of the key factors that identifies an organization as an insurgent group. Thus we hypothesize that:

H7: Organizations that control territory are more likely to use violence than organizations that do not control territory.

Recently Berman and others have made a compelling case for the provision of social services as a useful tool for organizations that want to use violence as a political tool (Clark, 2004; Flanigan, 2006; Berman, 2009; Szekely, 2014). Grynkewich (2008) points out that in some ways - like the control of territory - the provision of social services is a challenge to the state and an effort to replace the state. Berman goes further when he argues that when organizations provide social services - services like health, welfare and education related goods - the organization creates a situation where individuals become dependent on an organization for these goods, and this can buy their loyalty (Berman, 2009). Berman extends the logic of power that social services can provide an organization and suggests that this loyalty and dependence is a powerful force for recruiting people willing to engage in violence (Berman and Laitin 2008; Berman 2003, 2009). Berman argues that this explains the degree of violence achieved by groups as diverse as the Sicilian Mafia and Aum Shinrikyo. While the social services argument is compelling, it has mostly been tested within the context of the Middle East, and usually with a focus only on ex ante violent organizations. ${ }^{6}$ One of the advantages of our analysis is that we will be able to focus on violence within a different regional context than the Middle East to see if

\footnotetext{
${ }^{6}$ An exception is Asal et al. (2013), who find a relationship between social service provision and organization violence by Middle Eastern ethnopolitical groups - examining the broad sample of nonviolent and violent groups.
} 
social services have a similar effect in Eastern Europe and Russia as they appear to have in the Middle East. We hypothesize that:

H8: Organizations that provide social services are more likely to use violence than organizations that do not provide such services.

\section{Data and methodology}

To test our hypotheses we use the new Eastern European Minorities at Risk Organizational Behavior (MAROB) dataset, which has information on organizations that claim to represent ethnic or ethno-religious groups in Eastern Europe and Russia. ${ }^{7}$ As noted previously, all the groups in the dataset are identified as groups that claim to represent MAR groups as identified by Gurr (2000). They need to be politically active for at least three years and operate beyond the local level. The dataset does not include organizations created by governments, and it also excludes umbrella organizations. The dataset covers the years 19892006, and has information on 271 organizations in 23 countries in the region under discussion. The data was collected from academic research and newspaper articles as well as reports by governmental and nongovernmental organizations. See Table 1 for a list of the countries included in the sample, and a list of all organizations in the dataset can be found in the appendix.

[Table 1 about here.]

\footnotetext{
${ }^{7}$ It is similar to the Middle East MAROB dataset. The MAROB codebook is available at http://www.cidem.umd.edu/mar/data.asp.
} 
In this dataset, variables such as ideology are not coded as mutually exclusive. For example, an organization can be both nationalist and religious like the Chechen organization Ingush Jamaat. This also means that organizations can use a mixture of strategies and thus organizations can use both violent and nonviolent strategies. Similarly, the Communist Party of South Ossetia and the Democratic League of Kosovo used violence in the same year they ran for elections.

Due to missing data on some variables, the number of observations, and therefore groups, in models depends on the availability of data for those variables. The unit of analysis of the study is organization-year, and reported models have an $n$ of as many as 2,384, although other models have fewer observations because of missing data. Models include 261 or 251 of the 277 groups. Descriptive statistics for all the variables in the models can be found in Table 2. A correlation matrix appears in the online appendix..$^{8}$

[Table 2 about here.]

The dependent variable is Violence, a dichotomous variable coded 1 during years which the group has used violence as a strategy. While an ordinal or even categorical variable would be helpful for a number of reasons, unfortunately at this point there is only this dichotomous measure of violence. About $7 \%$ of group-years are coded as times that the group under

\footnotetext{
${ }^{8}$ The only variables with a correlation greater than .6 are territory and social services. However, if either of these is removed from the models, results do not change. For example, in Model 2, the primary model, territory remains statistically significant and positive when social services is excluded, and social services remains statistically insignificant when territory is excluded. As a result, it does not seem that multicollinearity is affecting results.
} 
observation engaged in this behavior. Around $17 \%$ of groups, 47, are coded for violence during at least one year in the sample. ${ }^{9}$

For hypothesis 1, we use two distinct measures. Interorganizational competition is a dichotomous variable coded 1 for years in which the group being analyzed has any visible manifestation of conflict with another ethnopolitical group. This can include, for example, individual acts of harassment, political agitation, or communal rioting. About $7 \%$ of group-years are coded for this variable, but about $17 \%$ of groups are coded for such conflict during at least one year. It should be noted that groups are coded for this variable whether they are in competition with another group of their own ethnic community, or with group of a different ethnic community. This is not ideal, as the outbidding hypothesis is about the first type of competition. However, there are theoretical reasons for either type of competition to produce violence, as discussed above.

A second measure of group competition is Indirect competition (groups in country). This is simply a count of the number of groups in the data set in the country of the group being analyzed during the particular year. It is a rougher measure of competition, but several studies of outbidding use exactly this type of measure in their analysis (Findley and Young 2012, Young and Dugan 2014). This provides a comparable measure, although we think the Interorganizational competition measure is more precise. The measures apparently capture distinct dimensions of competition - direct and indirect - as they are virtually uncorrelated. ${ }^{10}$

\footnotetext{
${ }^{9}$ To be clear, $7 \%$ refers to group-years, which is what is actually being analyzed in the quantitative study, while $17 \%$ refers to groups. Group descriptive data come from collapsing the data by group.

10 The correlation is .13.
} 
Hypothesis 2 is tested with Repression. This variable is coded 1 for group-years in which the organization is illegal and subject to periodic or ongoing repression by the state. About $30 \%$ of organization-years are coded for repression, and almost half of groups are repressed at some point during the sample.

Hypothesis 3 is tested with Strong leader, a dichotomous variable indicating a group with a single powerful leader, as opposed to an organization with a council-style leadership or fragmented group. About $8 \%$ of group-years are coded as having a strong leader, and about $11 \%$ of groups are in such a situation in the data at some point. The next hypothesis is tested with Unpopular organization, a variable coded "1" for "fringe" groups that have minimal support from the ethnic community they claim to support. Groups coded zero might be one of several popular groups, or the single popular group representing the community. About $19 \%$ of groupyears and $30 \%$ of groups are considered to be unpopular at least one year. ${ }^{11}$

Hypothesis 5 is tested with Foreign state support, which is coded 1 for years in which a group receives support from a foreign government. About $8 \%$ of group-years are coded for this, but about $19 \%$ of all groups receive foreign state support at some point during the sample. We use Diaspora support to test hypothesis 6, and this variable is coded 1 for years in which a group

${ }^{11}$ This variable is created using the MAROB variable Orgpop, which is an ordinal measure of organizational popularity where 1=fringle/unpopular groups, $2=$ one of several popular groups, and $3=$ the dominant group. Orgpop is missing data on several hundred group-years. To increase the size of the sample analyzed, we created a variable Orgpopconverted, where groups missing data on Orgpop are coded as being the lowest level of popularity, because we assume that if a group were more popular, this would be known. However, if a variable is used in the models that includes the missing group-years as missing, results are substantively the same. 
receives aid from members of the minority group that have been internationally dispersed. Only about $3 \%$ of group-years are coded for this, and about $6 \%$ of groups receive diaspora support at least one year. Hypothesis 7 is tested with Territory, a binary variable indicating if the group administers territory, whether controlling movement in and out of the area, or actually providing governing structures. About 3\% of group-years, and 7\% of groups, are coded for this. To test hypothesis 8 we include Social services, which is an ordinal variable, 0-2, measuring the degree to which an organization provides services such as education, healthcare, or poverty alleviation to constituents. About $12 \%$ of groups are coded for some non-zero level of this variable at least one year.

The models include a number of control variables, to take into consideration other factors that could be associated with a group's use of violence. The dichotomous variable Separatist is used, and groups are coded for this variable if their political motivations include a claim to national autonomy or independence. The choice of violence is often connected to the "...total rejection of the regime's legitimacy" (Sprinzak 1991, 52) and the ideology of ethnonationalism for groups that are advocating for a separate state is fundamentally a rejection of the regime's legitimacy. About 55\% of all groups are coded as having such goals. We also include the measure Religious, a dichotomous variable coded 1 if the group advocates policies that incorporate religion into public life. Juergensmeyer (2003) argues that religious ideology facilitiates the killing of opponents because it allows participants in conflict to see the other side 
as antagonists in a "cosmic war" where the enemy is evil. About $6 \%$ of groups are coded as religious. $^{12}$

Models also include a number of state-level measures for the country in which the organization operates. Regime type should also affect groups' likelihood of using violence. Organizations in democratic states have more opportunities to affect change non-violently, and therefore should avoid costly violence (Regan and Norton 2005, 333). State regime type is the Freedom House 1-3 measure, where 1 indicates "free" and 3 indicates "not free." We include two country-level economic measures, State GDPPC (log) and State GDPPC growth. Both measures come from the World Bank World Development Indicators. All three state-level variables were obtained via the Quality of Government data (Teorell et al. 2013).

Given the binary nature of the dependent variable, we use logistic regression for the analysis. Because organizations are measured multiple times (each year), standard errors are clustered by group (Woolridge 2003, Zorn 2006). Year dummies are included to address unmeasured temporal phenomena that might affect organizations, although they are not reported in the results for space reasons. The online appendix includes additional robustness checks, which are discussed below.

[Table 3 about here.]

\section{Analysis and discussion}

\footnotetext{
${ }^{12}$ Interestingly, there are far fewer religious groups in the Eastern Europe sample than in the Middle Eastern MAROB data. In the Middle Eastern data, about $25 \%$ of groups are coded as having a religious motivation (Asal et al. 2013).
} 
Results are shown in Table 3, which includes two models. The first model includes only organization-level attributes, and the second also includes state measures. Interorganizational competition is statistically significant and positive in both models, suggesting that when an ethnopolitical group is in direct competition with another ethnopolitical group, it is more likely than groups not in competition to use violence. This suggests support for the first hypothesis. The other measure, Indirect competition (groups in country), is not as robustly related to violence. In the model with state attributes, it is only associated with violence at the $p<.10$ level. In robustness checks in the online appendix, results are at that significance level or statistically insignificant. This suggests an interesting nuance for the outbidding hypothesis: only direct competition is associated with a group's use of violence. Indirect competition, measured as the number of groups in the country, is not consistently related to violence.

Repression is also statistically significant and positively signed in both models, indicating that when a group is a target of government repression, it is more likely than other groups to use violence. This is consistent with the second hypothesis. With Repression, as with Interorganizational competition, there is a possibility of reverse causality. However, if either of these independent variables is temporally lagged, its results are basically the same.

Strong leader is statistically significant and positively signed in both models as well, suggesting an ethnopolitical group with a single powerful leader is more likely to engage in violence than a group with another type of leadership structure. This supports the hypothesis. Unpopular group is also statistically significant and positively signed, consistent with expectations. Groups with little support from the broader ethnic community are more likely to use violence. 
There is some support for the "financial resources" hypotheses. Foreign state support is marginally statistically significant $(p<.10)$ in Model 1 , without state attributes. It is possible this is due to omitted variable bias. It is statistically significant and positive in Model 2, consistent with the hypothesis, but this result does not hold in all of the robustness checks shown in the online appendix. Overall, there is some evidence for an association between an ethnopolitical group receiving foreign state support and using violence. Diaspora support is statistically significant. There is support for hypothesis $6 .{ }^{13}$ Overall, the results of these two variables suggest some support for a connection between foreign funding and a group's propensity to use violence. The not-completely-robust results could be related to the fact, discussed in the theoretical section, that while funds are needed for substantial levels of organizational violence such as that seen in civil war, financial resources are less necessary for lower levels of violence.

Regarding hypothesis 7 , Territory is consistently positively signed and statistically significant. There is support for the hypothesis. Ethnopolitical organizations that control territory are more likely to engage in violence than groups that do not control territory.

Interestingly, Social services is statistically insignificant in all models. This goes against expectations. This is interesting because of arguments by Berman $(2003,2009)$ and others that social service provision should aid organizations in becoming especially violent. This argument has generally been tested in the Middle East, where it has found support (Asal et al. 2013). It fails to find support among Eastern European groups. An important nuance is that Berman does not suggest social services cause groups to use violence, just that they help a group with mobilization, enabling more effective violence for those groups already engaged in violence. It is

\footnotetext{
${ }^{13}$ Diaspora support is statistically significant and positively signed in two of the three of the robustness checks in the appendix.
} 
likely that many groups delivering community services do not engage in violence, but other research suggests the few that do will be especially effective at it. It is also possible that the relationship is found in the Middle East because social service provision is more common among ethnopolitical groups there, as is violence. Overall, the possible connection between social service provision and ethnopolitical violence is worthy of future research, but it does not find support among Eastern European groups.

The control variables also show interesting results. The coefficient for Separatist is statistically insignificant. Religious, however, is statistically significant and positive in all models, suggesting that if a group has a religious motivation, it is more likely than an ethnopolitical group without religious motivation to use violence. This is consistent with the literature.

Regarding state-level control variables, both State regime type and State GDPPC (log) are statistically significant and positively signed. Regarding regime type, the positive sign suggests more authoritarian states are more likely to see violence by ethnopolitical groups. It is interesting that this variable is related to violence independently from the relationship involving repression. Apparently there are aspects of regime type other than repression, such as lack of political alternatives, which could drive subnational groups to violence. Future research should look beyond repression to disaggregate the relationship between various dimensions of regime type and violence.

Regarding the positive relationship between violence and per capita wealth, this is unexpected, as research often finds poverty related to violence. This relationship is worth further examination, but it should be noted that the relationship between poverty and violence is for civil war, not all violence or specific types of violence such as terrorism. Some studies of terrorism 
find country wealth associated positively with that type of violence (e.g., Piazza 2011). It is important for scholars of conflict to remember that while poverty is apparently related to civil war onset, that is only one type of violence. The current article is primarily focused on organizational dynamics of conflict, but scholars should continue to examine relationships between broader economic factors and violence.

Regarding time, year fixed effects are often statistically significant and negative in Model 1 , where the omitted year is 1988 . This suggests groups are less likely to use violence in most years than in 1988. However, once state attributes are introduced in Model 2, most year variables are statistically insignificant. Apparently variation in state regime type and per capita income better explains violence than do particular years. A model in the online appendix includes a time trend variable, but it is statistically insignificant, suggesting there is not a general trend of increased or decreased likelihood of violence over time for ethnopolitical groups in Eastern Europe. It is negatively signed, but statistically insignificant.

Beyond the two models shown here, the results are generally robust to changes to model specification. In the online appendix, we include country fixed effects, and almost all the hypothesized results remain. ${ }^{14}$ Country fixed effects are helpful to take into consideration the myriad of country-level differences that could be associated with ethnonational violence. We do not include country fixed effects in all models, however, because about $25 \%$ of observations are

${ }^{14}$ Indirect competition (groups in country), which is borderline statistically insignificant in Model 2, is insignificant in the country fixed effects model. Diaspora support also becomes statistically insignificant when country fixed effects are included. All other hypothesized relationships hold. Beyond hypothesized relationships, the regime type and per capita income measures lose statistical significance in these models. 
dropped, substantially reducing the sample. This occurs because of the dichotomous nature of the dependent variable, and the fact that in some countries, none of the groups engage in violence. These countries drop from the sample with country fixed effects included, which means a systematic loss of observations because of the dependent variable value. Nonetheless, results are mostly robust in spite of the substantial sample change of country fixed effects models.

The appendix also includes a model with a measure of fuel export dependence (fuel exports as a percentage of exports), because resource curse can be an important source of grievances, ethnic or otherwise. The fuel dependence variable is statistically significant and positive, suggesting ethnopolitical groups in countries dependent on fuel exports are more likely to use violence. We do not include this variable in all models because it is missing data which causes a substantial number of observations to drop. Additionally, the focus of the article is on organizational attributes. However, most of the results shown in the main tables are robust in this model as well. ${ }^{15}$

Regarding substantive effects, marginal effects calculated from Model 2 suggest that Interorganizational competition and Territory are the variables associated with the greatest change in the probability for organizational violence. An Eastern European ethnopolitical group in competition with another such group is estimated to have a $11 \%$ greater likelihood of using violence than a group not in such competition, other factors held constant. The greatest effect is for groups holding territory, a 19\% greater likelihood of using violence than groups not holding territory. It is difficult to be sure about causation with this variable, however, as groups holding

\footnotetext{
${ }^{15}$ Territory loses statistical significance in the model with the resource curse control. However, this could be because the sample is substantially different due to missing data on the resource curse measure.
} 
territory perhaps have already shown some capability or willingness to use violence. Future research should look into this association between ethnopolitical groups holding territory and their use of violence, because the association is substantively strong.

Other hypothesized variables show substantial effects. Repression, Strong leader, Unpopular group, Foreign state support, and Diaspora support is each associated with a 4 to $6 \%$ increase in the likelihood of a group using violence. This magnitude of a change is relatively meaningful. For comparison, the control variable Religion is associated with a $6 \%$ increase in the likelihood of violence. Give the important role of religion in violence by subnational actors (e.g., Juergensmeyer 2003), it is noteworthy that other variables have a similar effect.

Taken together, the overall results shown in Table 3 suggest diverse types of factors such as interorganizational and resource-related - are associated with the use of violence by Eastern European ethnopolitical groups. The result associated with repression suggests that government policies can have serious and counterproductive consequences. Interorganizational competition, perhaps underanalyzed in studies of political groups, and certainly in the literature on political violence, seems to play an extremely important role. The use of measures of two dimensions of competition, direct and indirect, allows us to test which type of competition could be especially associated with group violence. This adds nuance to our understanding of outbidding.

Beyond competition, the organizational dynamics of leadership type and unpopularity of the group apparently have an important association with violence. Other factors, primarily holding territory, foreign state support, and receiving support from a diaspora, seem to relate directly to power or funding opportunities. Finally, the lack of relationship between social service provision and violence is surprising, and worth further investigation. 
It is important to again acknowledge the regional limitations of our analysis. Like studies in the Middle East and other areas of the world, this study is dealing with a particular region that has traits that differentiate it in key ways from other regions (see for example Asal et al. 2013). This likely explains why the present research finds results that are different from those found by studies of other regions. In analysis of Middle Eastern ethnic organizations, there was no relationship between state regime type or group religiosity and violence (Asal et al. 2013), while we found autocracy and religious motivations related to violence. Additionally, the Middle Eastern study found social service provision related to violence, while we did not. Overall, this examination of Eastern European and Russian violent and nonviolent minority ethnopolitical organizations allows us to compare similar groups and to extend this analysis to a different region.

\section{Conclusion}

Why do some ethnopolitical organizations engage in violence, while others choose nonviolent means to attempt to bring about political change? This question is important for both research on ethnic politics and the literature on political violence. In research on political violence in particular, studies tend to focus on the state as the unit of analysis, overlooking important organizational attributes. Studies of organizations and political violence almost always look at already-violent groups. To address the question of ethnopolitical violence in a fresh way, we emphasize the importance of organizational dynamics, and particularly the role of resources, and build an argument for which organizational attributes should matter in explaining violence. To test our argument, we focused on Eastern European ethnopolitical groups, an important and diverse sub-set of organizations. Most of these groups do not use violence. The results support some hypotheses from the literature, such as interorganizational competition and repression, 
while failing to support some arguments such as a positive relationship between social service provision and violence.

The results complement and contrast with extant research in interesting ways. For example, some research suggests that competition among violent groups is associated with increased violence. Our study sheds light on interorganizational competition at an earlier stage in the process, finding that competition between groups is associated with a greater likelihood of a group using violence in the first place. This relationship appears when we measure competition directly (when a group has been observed to be in competition with another), as opposed to the proxy of the number of groups in the country. Similarly, the finding that repression of a group is associated with that group's use of violence adds to the work on how state repression can affect subnational groups' behavior. The apparent relationship between a group's lack of popularity and its use of violence is also interesting, adding evidence to arguments that violence is sometimes a tool of last resort or a weapon of the weak. Regarding funding, in spite of the substantial literature on the economic roots of subnational violence, it is remarkable that the hypotheses about foreign state support and diaspora support were not as sustained by the empirical tests as other hypotheses. While there was some support for the idea of an association between these funding sources and violence, other factors seem to be much more important.

It is noteworthy that social service provision is not associated with groups using violence. Berman argues that social services provide tools for helping violent groups to become much more violent. Why is there no relationship between social service provision and violence among Eastern Europe groups? More nuanced analysis of the relationship between social service provision and violence would contribute to our understanding of these phenomena. As noted above, there could be a multi-stage process, where organizations providing social services are no 
more likely than other groups to engage in violence (the results of this study), but for the few social service groups that do engage in violence, they are especially effective at it (Berman's results).

Future research can take a number of additional directions. First, because the study analyzed Eastern European groups, it is unclear how generalizeable the results are to other regions. Some results are consistent with those of studies of other regions, but global analyses and research on other regions and groups with other motivations will be fruitful. Related to this, there are a number of factors unique to this region that could play a role in organizational violence, but unfortunately we do not currently have data on all these factors. For example, groups in ethnofederalist states and autonomous regions have tools such as administrative resources that make successful secession more likely (Roeder 1991, 2009; Bunce 2004). Which of the groups in the data have access to administrative resources because of the structure of the state in which they operate, or the antecedent structure of that state? Additionally, this study found a relationship between holding territory and the use of violence, but holding territory occurs in many different ways. Does the location of the territory, relative to the capital or borders, matter? Further study of these dynamics would be interesting to explore.

Second, when groups choose to engage in violence, why do some target civilians while others directly take on state security forces? Some studies have started to consider this question, generally in terms of terrorism vs. insurgency, but much remains to be explored. Along somewhat similar lines, this study sought to explain organizational violence generally, but do the same factors explain escalations to more serious or longer-term use of violence? The interstate war literature has looked at conflict as a process, with "steps to war," but literature on subnational violence should take more seriously such dynamics (e.g., Moore 1998). Finally, the 
results of this study suggest an important effect of inter-organizational competition or disputes. A handful of other studies have examined this type of intergroup behavior as it relates to political violence (e.g., Bloom 2005, Nemeth 2013), but we still know little about other consequences of competition between subnational political organizations (e.g., Phillips 2015), or why competition emerges in some contexts but not in others. 


\section{Tables}

Table 1. Countries with organizations included in data

Albania

Azerbaijan

Belarus

Bosnia

Bulgaria

Croatia

Czech Republic

Estonia

Georgia

Hungary

Kazakhstan

Kyrgyzstan

Latvia

Lithuania

Macedonia

Moldova

Romania

Russia

Slovakia

Tajikistan

Turkmenistan

Ukraine

Yugoslavia 
Table 2. Variables and Descriptive Statistics

\begin{tabular}{llllll}
\hline Variable & Observations & Mean & Std. Dev. & Min. & Max. \\
\hline Violence (DV) & 2,588 & .074 & .262 & 0 & 1 \\
$\begin{array}{l}\text { Interorganizational } \\
\text { competition }\end{array}$ & 2,600 & .069 & .254 & 0 & 1 \\
$\begin{array}{l}\text { Indirect competition } \\
\text { (groups in country) }\end{array}$ & 2,633 & 17.089 & 12.305 & 1 & 41 \\
Repression & & & & & \\
Strong leader & 2,630 & .293 & .455 & 0 & 1 \\
Unpopular organization & 2,633 & .193 & .394 & 0 & 1 \\
Foreign state support & 2,557 & .084 & .278 & 0 & 1 \\
Diaspora support & 2,584 & .028 & .165 & 0 & 1 \\
Territory & 2,633 & .034 & .182 & 0 & 1 \\
Social services & 2,610 & .107 & .404 & 0 & 2 \\
Separatist & 2,602 & .548 & .498 & 0 & 1 \\
Religious & 2,625 & .059 & .236 & 0 & 1 \\
State regime type & 2,564 & 1.933 & .638 & 1 & 3 \\
State GDPPC (log) & 2,448 & 8.700 & .625 & 6.743 & 10.029 \\
State GDPPC growth & 2,430 & .418 & 3.627 & -30.694 & 90.468 \\
\hline & & & & & 1 \\
\hline
\end{tabular}


Table 3. Logistic regressions of violence by Eastern European ethnopolitical groups

Model 1

Group attributes only

\begin{tabular}{|c|c|c|}
\hline & $(.458)$ & $(.485)$ \\
\hline $\begin{array}{l}\text { Indirect competition } \\
\text { (groups in country) }\end{array}$ & $.0643 * * *$ & $.0482^{*}$ \\
\hline Repression & $\begin{array}{c}1.519^{* * * *} \\
(.399)\end{array}$ & $\begin{array}{c}1.303^{* * * *} \\
(.410)\end{array}$ \\
\hline Strong leader & $\begin{array}{c}2.306^{* * * *} \\
(.470)\end{array}$ & $\begin{array}{c}2.072 * * * \\
(.528)\end{array}$ \\
\hline Unpopular group & $\begin{array}{c}1.024 * * \\
(.424)\end{array}$ & $\begin{array}{c}1.212 * * * \\
(.436)\end{array}$ \\
\hline Foreign state support & $\begin{array}{l}1.091^{*} \\
(.628)\end{array}$ & $\begin{array}{c}1.765^{* * * *} \\
(.598)\end{array}$ \\
\hline Diaspora support & $\begin{array}{c}1.699 * * \\
(.845)\end{array}$ & $\begin{array}{c}1.839^{* *} \\
(.823)\end{array}$ \\
\hline Territory & $\begin{array}{l}5.397^{* *} \\
(2.119)\end{array}$ & $\begin{array}{l}6.107 * * \\
(2.778)\end{array}$ \\
\hline Social services & $\begin{array}{l}-1.593 \\
(.982)\end{array}$ & $\begin{array}{l}-1.787 \\
(1.301)\end{array}$ \\
\hline Separatist & $\begin{array}{l}.753 \\
(.642)\end{array}$ & $\begin{array}{l}.676 \\
(.596)\end{array}$ \\
\hline Religious & $\begin{array}{c}2.204^{* * * *} \\
(.620)\end{array}$ & $\begin{array}{c}1.948^{* * * *} \\
(.617)\end{array}$ \\
\hline State regime type & & $\begin{array}{l}.700^{* * * *} \\
(.222)\end{array}$ \\
\hline State GDPPC $(\log )$ & & $\begin{array}{c}1.369^{* * * *} \\
(.408)\end{array}$ \\
\hline State GDPPC growth & & $\begin{array}{c}.006 \\
(.018)\end{array}$ \\
\hline Constant & $\begin{array}{c}-5.753^{* * * *} \\
(.948)\end{array}$ & $\begin{array}{l}-19.59^{* * *} \\
(3.602)\end{array}$ \\
\hline $\begin{array}{l}\mathrm{N} \\
\text { (groups) }\end{array}$ & $\begin{array}{l}2,384 \\
(261) \\
\end{array}$ & $\begin{array}{l}2,231 \\
(251)\end{array}$ \\
\hline
\end{tabular}

Standard errors shown under coefficients, clustered by group. Year fixed effects included but not shown for space reasons. $* \mathrm{p}<.10, * * \mathrm{p}<.05, * * * \mathrm{p}<.01$

Model 2

With state attributes

$(.485)$

$.0482^{*}$

(.410)

$(.528)$

$.212 * * *$

(.436)

$1.765^{* * * *}$

(.598)

(.823)

6.107 **

(2.778)

$-1.787$

(1.301)

.676

(.596)

(.617)

$700 * * *$

(.408)

.006

(3.602)

2,231 


\section{References}

Abrahms, Max, and Philip B. K. Potter. 2015. "Explaining Terrorism: Leadership Deficits and Militant Group Tactics.” International Organization 69 (2): 311-342.

Aksoy, Deniz, David B. Carter, and Joseph Wright. 2012. Terrorism in Dictatorships. Journal of Politics 74 (3):810-826.

Asal, Victor, Richard Legault, Ora Szekely, and Jonathan Wilkenfeld. "Gender ideologies and forms of contentious mobilization in the Middle East." Journal of Peace Research 50, no. 3 (2013): 305-318.

Asal, Victor, Amy Pate and Jonathan Wilkenfeld. 2008. Minorities at Risk Organizational Behavior Data and Codebook Version 9/2008 online: http://www.cidcm.umd.edu/mar/data.asp

Berman, Eli. 2009. Radical, religious, and violent: the new economics of terrorism. The MIT Press.

Blimes, Rand. "The Indirect Effect of Ethnic Hetereogeneity on the Likelihood of Civil War Onset.” 2006. Journal of Conflict Resolution 50 (4): 536-547.

Bloom, Mia M. 2004. "Palestinian suicide bombing: Public support, market share, and outbidding.” Political Science Quarterly 119 (1): 61-88.

Bloom, Mia M. 2005. Dying to Kill: The Allure of Suicide Terrorism. New York: Columbia University Press.

Braithwaite, Alex, Dennis M. Foster, and David Sobek. 2012. There Can Be No Compromise: Institutional Inclusiveness, Fractionalization and Domestic Terrorism. British Journal of Political Science 43 (3):541-557. 
Bunce, Valerie. 2004. "Is Ethnofederalism the Solution or the Problem?" In Alina MungiuPippidi and Ivan Krastev, eds., Nationalism After Communism: Lessons Learned. Budapest: Central European, 2004, pp. 179-198.

Byman, Daniel. 2005. Deadly Connections: States that Sponsor Terrorism. Cambridge: Cambridge University Press.

Carter, David B. 2012. A Blessing or a Curse? State Support for Terrorist Groups. International Organization 66 (1):129-151.

Cederman, L.E., A. Wimmer, and B. Min. 201. Why do ethnic groups rebel? New data and analysis. World Politics 62 (01): 87-119.

Chenoweth, Erica. 201. Democratic Competition and Terrorist Activity. Journal of Politics 72 (1): 16-3.

Chenoweth, Erica., and M.J. Stephan. 2011. Why civil resistance works: The strategic logic of nonviolent conflict. Columbia University Press.

Chivers, CJ. 2007. THE SCHOOL The inside story of the 2004 attack in Beslan. ESQUIRE. March 14, 2007.

Christin, Thomas, and Simon Hug. 2012. Federalism, the Geographic Location of Groups, and Ethnic Conflict. Conflict Management and Peace Science.29 (1): 93-122.

Collier, Paul, and Anke Hoeffler. 2004. Greed and Grievance in Civil War. Oxford Economic Papers 56:563-595.

Collier, Paul, Lani Elliott, Havard Hegre, Anke Hoeffler, Marta Reynal-Querrol, and Nicholas Sambanis. 2003. Breaking the Conflict Trap: Civil War and Development Policy. Oxford: World Bank and Oxford University Press. 
Conrad, Justin, and Kevin A. Greene. 2015. "Competition, Differentiation, and the Severity of Terrorist Attacks.” The Journal of Politics 77 (2): 546-561.

Cunningham, David E. 2006. Veto Players and Civil War Duration. American Journal of Political Science 50 (4):875-892.

Cunningham, David E., Kristian Skrede Gleditsch, and Idean Salehyan. 2009. It Take Two: A Dyadic Analysis of Civil War Duration and Outcome. Journal of Conflict Resolution 53 (4): 570-597.

Cunningham, Kathleen Gallagher. 2013. Actor Fragmentation and Civil War Bargaining: How Internal Divisions Generate Civil Conflict. American Journal of Political Science 57 (3): 659-672.

della Porta, Donatella. 2013. "Clandestine Political Violence.” Cambridge: Cambridge University Press.

di. Giovanni, Janine. 2000. "Evil Things Happened Here.” In The Times of London. February, 2000.

Fearon, James D., and David D. Laitin. 2003. Ethnicity, Insurgency, and Civil War. American Political Science Review 97 (1):75-9.

Findley, Michael G., and Joseph K. Young. 2012. "More combatant groups, more terror?: Empirical tests of an outbidding logic.” Terrorism and Political Violence 24 (5): 706721.

Ford, Christopher M. 2005. “Speak No Evil: Targeting a Population's Neutrality to Defeat an Insurgency.” Parameters: United States Army War College Quarterly (Summer 2005), v.35 no.2, p.51-66. 
Francisco, Ronald A. 2005. The Dictator's Dilemma. In Repression and Mobilization, edited by C. Davenport, H. Johnston and C. Mueller. Minneapolis: University of Minnesota Press.

Giraldo, Jeanne K. and Harold A. Trinkunis (eds.). 2007. Terrorism Financing and State Responses. Stanford, CA: Stanford University Press.

Goodwin, Jeff. 2001. No Other Way Out: States and Revolutionary Movements, 1945-1991. Cambridge: Cambridge University Press.

Grynkewich, Alexus G. 2008. "Welfare as warfare: How violent non-state groups use social services to attack the state." Studies in Conflict \& Terrorism 31 (4): 350-37.

Gurr, Ted Robert, and Will H. Moore. 1997. "Ethnopolitical Rebellion: A Cross-Sectional Analysis of the 1980s with Risk Assessments for the 1990s." American Journal of Political Science 41 (4): 1079-1103.

Gurr, Ted Robert. 200. People vs. States. Washington D.C: United States Institute of Peace. Hegre, Havard, and Nicholas Sambanis. 2006. "Sensitivity Analysis of the Empirical Results on Civil War Onset." Journal of Conflict Resolution 50 (4): 508-535.

Horowitz, Donald L. 1985. Ethnic Groups in Conflict. Berkeley: University of California Press. Inclán, María de la Luz. 2009. Repressive Threats, Procedural Concessions, and the Zapatista Cycle of Protests, 1994-2003. Journal of Conflict Resolution 53 (5):794-819.

Juergensmeyer, Mark. 2003. Terror in the Mind of God: The Global Rise of Religious Violence. Third ed. Berkley: University of California Press.

Karklins, Ramsa, and Roger Peterson. 1993. Decision Calculus of Protesters and Regimes: Eastern Europe 1989. Journal of Politics 55 (3):588-614.

Kaufman, Stuart J. 2006. Symbolic Politics or Rational Choice? Testing Theories of Extreme Ethnic Violence. International Security 30 (4):45-86. 
Lichbach, Mark I. 1987. Deterrence or Escalation? The Puzzle of Aggregate Studies of Repression and Dissent. Journal of Conflict Resolution 31 (2):266-297.

Lichbach, Mark Irving. 1995. The Rebel's Dilemma University of Michigan Press. Ann Arbor: University of Michigan Press

Lieven, Anatol. (1998) Chechnya: Tombstone of Russian Power. New Haven and London: Yale University Press.

Lynch, Dov . 2005. 'The enemy is at the gate':1 Russia after Beslan. International Affairs 81 (1): $141-161$.

Makarenko, Tamara. 2004. “The Crime-Terror Continuum: Tracing the Interplay Between Transnational Organised Crime and Terrorism.” Global Crime 6(1): 129-45.

Mampilly, Zachariah Cherian. 2011. Rebel Rulers: Insurgent governance and civilian life during war. Cornell University Press.

Marshall, Monty G., and Keith Jaggers. 2002. Polity IV Project. Political Regime Characteristics and Transitions, 1800-2002. Dataset Users' Manual. Center for International Development and Conflict Management (CIDCM). University of Maryland.

McCarthy, John D., and Mayer N. Zald. 1977. Resource Mobilization and Social Movements: A Partial Theory. The American Journal of Sociology 82 (6):1212-1241.

Montalvo, Jose G., and Marta Reynol-Querol. 2005. Ethnic Polarization, Potential Conflict, and Civil War." American Economic Review 95 (3): 796-816.

Moore, Will H. 1998. Repression and Dissent: Substitution, Context, and Timing. American Journal of Political Science 42 (3):851-873. 
Moscardino, Ughetta, et al. Narratives from caregivers of children surviving the terrorist attack in Beslan: Issues of health, culture, and resilience." Social Science \& Medicine 64.8 (2007): 1776-1787.

Nemeth, Stephen. 2014. The Effect of Competition on Terrorist Group Operations, Journal of Conflict Resolution 58 (2): 336-362.

Ó Tuathail, Gearóid. "Placing blame: Making sense of Beslan.” Political Geography 28.1 (2009): 4-15.

Opp, Karl-Dieter, and Wolfgang Roehl. 199. Repression, Micromobilization, and Political Protest. Social Forces 69 (2):521-547.

Pearlman, Wendy, and Kathleen Gallagher Cunningham. 2012. Nonstate Actors, Fragmentation, and Conflict Processes. Journal of Conflict Resolution 56 (1):3-15.

Phillips, Brian J. 2015. “Enemies with Benefits? Violent Rivalry and Terrorist Group Longevity." Journal of Peace Research 52 (1): 62-75.

Piazza, James A. 2011. "The Illicit Drug Trade, Counternarcotics Strategies, and Terrorism." Public Choice 149 (3-4), 297-314.

Powell Jr, G. Bingham. 1982. Contemporary Democracies: Participation, Stability, and Violence. Cambridge, MA: Harvard University Press.

Regan, Patrick M., and Daniel Norton. 2005. Greed, Grievance, and Mobilization in Civil Wars. Journal of Conflict Resolution 49 (3):319-336.

Regan, Patrick M. 2002. Civil Wars and Foreign Powers: Outside Intervention in Intrastate Conflict. Ann Arbor: University of Michigan Press.

Roeder, Philip G. 1991. "Soviet Federalism and Ethnic Mobilization.” World Politics 43 (2): $196-232$. 
Roeder, Philip G. 2009. "Ethnofederalism and the mismanagement of conflicting nationalisms." Regional and Federal Studies 19(2): 203-219

Saideman, Stephen M., David J. Lanoue, Michael Campenni, and Samuel Stanton. 2002. Democratization, Political Institutions, and Ethnic Conflict: A Pooled Time-Series Analysis, 1985-1998. Comparative Political Studies 35 (1):103-129.

Sambanis, Nicholas. 2001. "Do Ethnic and Nonethnic Civil Wars Have the Same Causes?: A Theoretical and Empirical Inquiry (Part 1).” Journal of Conflict Resolution 45 (3): 259282.

Sánchez-Cuenca, Ignacio, and Luis De la Calle. 2009. Domestic terrorism: The hidden side of political violence. Annual Review of Political Science 12: 31-49.

Shapiro, Jacob. 2013. The Terrorist's Dilemma: Managing Violent Covert Organizations. Princeton: Princeton University Press.

Sprinzak, Ehud. 1991. The process of delegitimation: Towards a linkage theory of political terrorism. Terrorism and Political Violence 3 (1): 50-68.

Szekely, Ora. 2014. "Doing Well by Doing Good: Understanding Hamas's Social Services as Political Advertising." Studies in Conflict and Terrorism 38 (4): 275-292.

Takeyh, Ray, and Nikolas K. Gvosdev. 2002. "Do Terrorist Networks Need a Home?" The Washington Quarterly 25(3): 97-108.

Teorell, Jan, Nicholas Charron, Stefan Dahlberg, Sören Holmberg, Bo Rothstein, Petrus Sundin \& Richard Svensson. 2013. The Quality of Government Basic Dataset made from The Quality of Government Dataset, version 15May13. University of Gothenburg: The Quality of Government Institute, http://www.qog.pol.gu.se.

Tilly, Charles. 1978. From Mobilization to Revolution. New York: McGraw Hill. 
Weinberg, Leonard. 1991. Turning to Terror: The Conditions under Which Political Parties Turn to Terrorist Activities. Comparative Politics 23 (4): 423-438.

Weinstein, Jeremy. 2006. Inside Rebellion: The Politics of Insurgent Violence. Cambridge: Cambridge University Press.

Williams, Phil. 2001. Transnational Criminal Networks. In Networks and Netwars: The Future of Terror, Crime, and Militancy, edited by J. Arquilla and D. Ronfeldt. Santa Monica, CA: RAND.

Wilson, James Q. 1973. Political Organizations. New York, NY: Basic Books.

Woolridge, Jeffrey M. 2003. Cluster-Sample Methods in Applied Econometrics. The American Economic Review 93 (2):133-138.

Young, Joseph K., and Laura Dugan. 2014. "Survival of the Fittest: Why Terrorist Groups Endure." Perspectives on Terrorism 8 (2), 2-23.

Zorn, Christopher. 2006. Comparing GEE and Robust Standard Errors for Conditionally Dependent Data. Political Research Quarterly 59 (3):329-341. 